\title{
Pembelajaran Nilai Agama dan Moral Anak Usia Dini melalui Metode Montessori selama Pandemi Covid-19
}

\author{
Dhiah Intan Permataputri ${ }^{1 凶}$, Amir Syamsudin ${ }^{2}$ \\ Pendidikan Anak Usia Dini, Universitas Negeri Yogyakarta \\ DOI: $10.31004 /$ obsesi.v6i2.1042
}

\begin{abstract}
Abstrak
Nilai Agama dan Moral (NAM) perlu ditanamkan sejak usia dini untuk bekal anak di usia tumbuh kembang selanjutnya. Tujuan penelitian ini untuk mendeskripsikan pelaksanaan pembelajaran NAM melalui metode montessori selama pandemi covid-19. Penelitian ini dianalisis dengan metode kualitiatif deskriptif. Subjek dipilih menggunakan teknik sampel nonprobability sampling yaitu purposive sample. Terdapat 5 subjek penelitian yang terdiri dari 2 orang guru kelas, 2 orang tim kurikulum, dan 1 orang kepala sekolah. Penelitian ini menggunakan wawancara mendalam dan dokumentasi untuk mengumpukan data dengan proses analisis melalui empat tahapan yaitu reduksi data, display data, kesimpulan serta verifikasi data. Berdasarkan hasil wawancara dengan subjek penelitian disimpulkan bahwa pembelajaran NAM selama pandemi covid-19 dilakukan dengan media sosial (zoom dan whatsapp). Pembelajaran NAM dikolaborasikan dengan metode montessori yang berpusat pada anak dan mengajarkan mengenai life skill, sehingga anak mudah memahami dan memiliki keterampilan hidup.
\end{abstract}

Kata Kunci: pembelajaran nilai agama moral; montessori; covid 19; anak usia dini.

\begin{abstract}
Religious and Moral Values (NAM) need to be instilled from an early age to provide children with the next developmental age. The purpose of this study was to describe the implementation of NAM learning through the montessori method during the Covid-19 pandemic. This research was analyzed using descriptive qualitative method. Subjects were selected using nonprobability sampling technique, namely purposive sample. There were 5 research subjects consisting of 2 classroom teachers, 2 curriculum teams, and 1 school principal. This study uses in-depth interviews and documentation to collect data with the analysis process through four stages, namely data reduction, data display, conclusion and data verification. Based on the results of interviews with research subjects, it was concluded that NAM learning during the Covid-19 pandemic was carried out using social media (zoom and whatsapp). Learning NAM is collaborated with the childcentered montessori method and teaches life skills, so that children can easily understand and have life skills.
\end{abstract}

Keywords: learning moral religious values; montessori; covid 19; early childhood.

Copyright (c) 2021 Dhiah Intan Permataputri, Amir Syamsudin

$\triangle$ Corresponding author:

Email Address : intan.permataputri.ip@gmail.com (Yogyakarta, Indonesia)

Received 8 January 2021, Accepted 1 April 2021, Published 25 June 2021 


\section{PENDAHULUAN}

Masa kanak-kanak awal merupakan salah satu masa yang sangat penting dalam kehidupan seorang manusia, hal ini dikarenakan mulai munculnya rasa peka atau sensitif anak terhadap berbagai macam rangsangan yang muncul dari lingkungan sekitar anak (Hapsari, 2016). Sebutan lain untuk masa ini adalah golden age, masa emas di mana otak anak mengalami perkembangan pesat yang berlangsung pada rentang usia nol sampai enam tahun (Fauziddin, 2016a). Oleh karena itu, perkembangan anak pada masa emas ini dapat berlangsung melalui lembaga Pendidikan Anak Usia Dini (PAUD). Pendidikan Anak Usia Dini (PAUD) merupakan sebuah lembaga yang memberikan stimulasi terhadap pertumbuhan dan perkembangan anak usia nol sampai enam tahun dalam hal jasmani maupun rohani agar anak memiliki kesiapan untuk jenjang pendidikan berikutnya (Kementerian Pendidikan Dan Kebudayaan, 2003). Menurut Permendikbud nomor 37 tahun 2014 dijelaskan bahwa Terdapat 6 aspek perkembangan yang harus dikembangkan oleh Pendidikan Anak Usia Dini (PAUD), keenam aspek tersebut adalah aspek perkembangan nilai agama dan moral, koginitf, sosial emosional, bahasa, fisik motorik, dan seni (Kementerian Pendidikan Dan Kebudayaan, 2014).

Salah satu aspek perkembangan yang dikembangkan dalam lembaga PAUD adalah aspek perkembangan Nilai Agama dan Moral. Penanaman nilai agama dan moral yang kuat bertujuan agar anak memiliki keyakinan yang kuat agar tidak terpengaruh dan dapat menyaring hal-hal buruk di sekitarnya (Fauziddin, 2016b). Perkembangan aspek nilai agama dan moral erat kaitannya dengan budi pekerti, sikap sopan santun, kemauan melaksanakan ajaran agama dalam kehidupan anak sehari-hari (Lestariningrum, 2014). Beberapa waktu terakhir, berbagai fenomena perilaku negatif sering terlihat dalam keseharian anak melalui surat kabar, televisi, atau media sosial, misalnya kurangnya sopan santun, meniru adegan kekerasan, dan meniru perilaku yang tidak pantas dilakukan oleh anak. Melihat kondisi ini tentunya sangat memprihatinkan, mengingat bahwa dunia yang anak jalani harusnya belajar dengan berbagai macam permainan yang menyenangkan (Setiawati, 2006).

Tantangan lain dalam penanaman nilai agama dan moral adalah kondisi pelaksanaan pembelajaran yang berbeda dari yang sudah dijalani selama ini. Hal ini dikarenakan Indonesia merupakan salah satu dari banyak negara di dunia yang sedang berjuang menanggulangi Corona Virus Disease (Covid-19), wabah ini menyerang pernafasan (World Health Organization, 2020). Covid-19 merupakan penyakit yang tegolong baru dimana penyebab, asal muasal virus ini belum diketahui secara pasti (Chan et al., 2020). Pasien Covid-19 yang bertambah begitu cepat berpengaruh pada aktivitas di berbagai bidang, salah satunya yang terdampak adalah bidang pendidikan (Mamun et al., 2020). Sebagai upaya penanggulangan Covid-19, Pemerintah Indonesia mengeluarkan kebijakan mengenai pemberlakuan pembatasan sosial (sosial distancing), pembatasan fisik (physical distancing) (Tim Kerja Kementerian Dalam Negeri, 2020) dan Pembatasan Sosial Berskala Besar (PSBB) (Azanella, 2020). Bentuk pelaksanaan PSBB dalam bidang pendidikan sesuai dengan yang tercantum dalam Permenkes RI No. 9 Tahun 2020 adalah bergesernya proses pembelajaran di sekolah menjadi belajar di rumah menggunakan media yang efektif (Kementerian Kesehatan, 2020). Hal ini tentunya menjadi tantangan baru untuk melaksanakan pembelajaran jarak jauh, sebab lembaga-lembaga pendidian masih sedikit pengalaman mengenai kebijakan tersebut (Aji, 2020). Model pembelajaran jarak jauh dirasa sangat cocok dilaksanakan di masa pandemi Covid-19 karena dapat dilakukan tanpa harus bertatap muka secara langsung dan hanya melalui media virtual classroom seperti zoom, google meet, skype, dan lain sebagainya. Selain platform dan situs edukasi yang telah tersedia, pemanfaatan siaran televisi edukasi juga diperlukan sebagai penunjang (Zhou et al., 2020).

Salah satu lembaga PAUD yang menjalankan pembelajaran jarak jauh adalah SAFA Islamic Preschool. SAFA Islamic Preschool merupakan lembaga PAUD yang mengadaptasi kurikulum montessori dan diselaraskan dengan ajaran-ajaran agama Islam. Tentunya, sekolah ini juga sangat mendukung stimulus anak pada aspek nilai agama dan moral. Menurut Hainstock (2008), metode montessori merupakan bentuk pembelajaran yang menggunakan 
pendekatan individual, di mana anak dapat mengatur apa yang akan dipelajari dan bagaimana cara belajarnya, juga menggunakan media pembelajaran sesuai kreatifitasnya sehingga peran guru adalah sebagai fasilitator dan memantau kegiatan anak. Metode montessori memotivasi anak untuk dapat menciptakan potensi diri dengan maksimal untuk mencapai sebuah tujuan pendidikan yang diharapkan. Montessori berpendapat bahwa anak merupakan pembelajar yang aktif, sehingga metode ini menyediakan lingkungan yang menyenangkan bagi anak untuk membangun pengetahuannya secara mandiri (Damayanti, 2020). Selain itu, hasil penelitian dari Muthmainah (2017) penanaman nilai agama pada anak dapat dilakukan dengan metode montessori yang memiliki prinsip berpusat pada anak dan anak dapat belajar sesuai kemampuannya tanpa mengklasifikasikan usia. Sedangkan penelitian lainnya menyimpulkan bahwa pembelajaran dengan menggunakan metode montessori dapat menstimulasi perkembangan karakter anak (Wulandari et al., 2018).

Berdasarkan pemaparan di atas mengenai betapa pentingnya penanaman nilai agama dan moral bagi kehidupan anak dan munculnya tantangan baru dalam proses pembelajaran pada bidang pendidikan akibat wabah Covid-19, maka dalam artikel ini akan dibahas lebih lanjut mengenai pelaksanaan pembelajaran nilai agama dan moral melalui pendekatan montessori di SAFA Islamic Preschool saat pandemi Covid-19 berlangsung. Pada artikel ini akan dibahas mengenai pembelajaran NAM dengan menggunakan kurikulum 2013 yang dikolaborasikan metode montessori juga diselaraskan dengan nilai-nilai agama Islam.

\section{METODOLOGI}

Penelitian ini dianalisis dengan metode kualitiatif deskriptif yang dirancang untuk mendeskripsikan pelaksanaan pembelajaran Nilai Agama dan Moral melalui pendekatan Montessori di masa pandemi Covid-19. Subjek dipilih menggunakan teknik sampel nonprobability sampling yaitu purposive sample (pemilihan sampel dengan pertimbangan tertentu). Kriteria pemilihan sampel yaitu: 1) Pihak sekolah yang bertanggungjawab atas jalannya pembelajaran 2) Pihak sekolah yang bertanggungjawab atas penyusunan kurikulum. Penelitian menggunakan 5 subjek dari SAFA Islamic Preschool yang terdiri dari kepala sekolah, 2 guru penyusun kurikulum, dan 2 guru kelas TK A dan TK B. Hasil wawancara peneliti ditentukan 5 subjek yang memenuhi kriteria pemilihan sampel, yaitu KS, G1, G2, K1, K2.

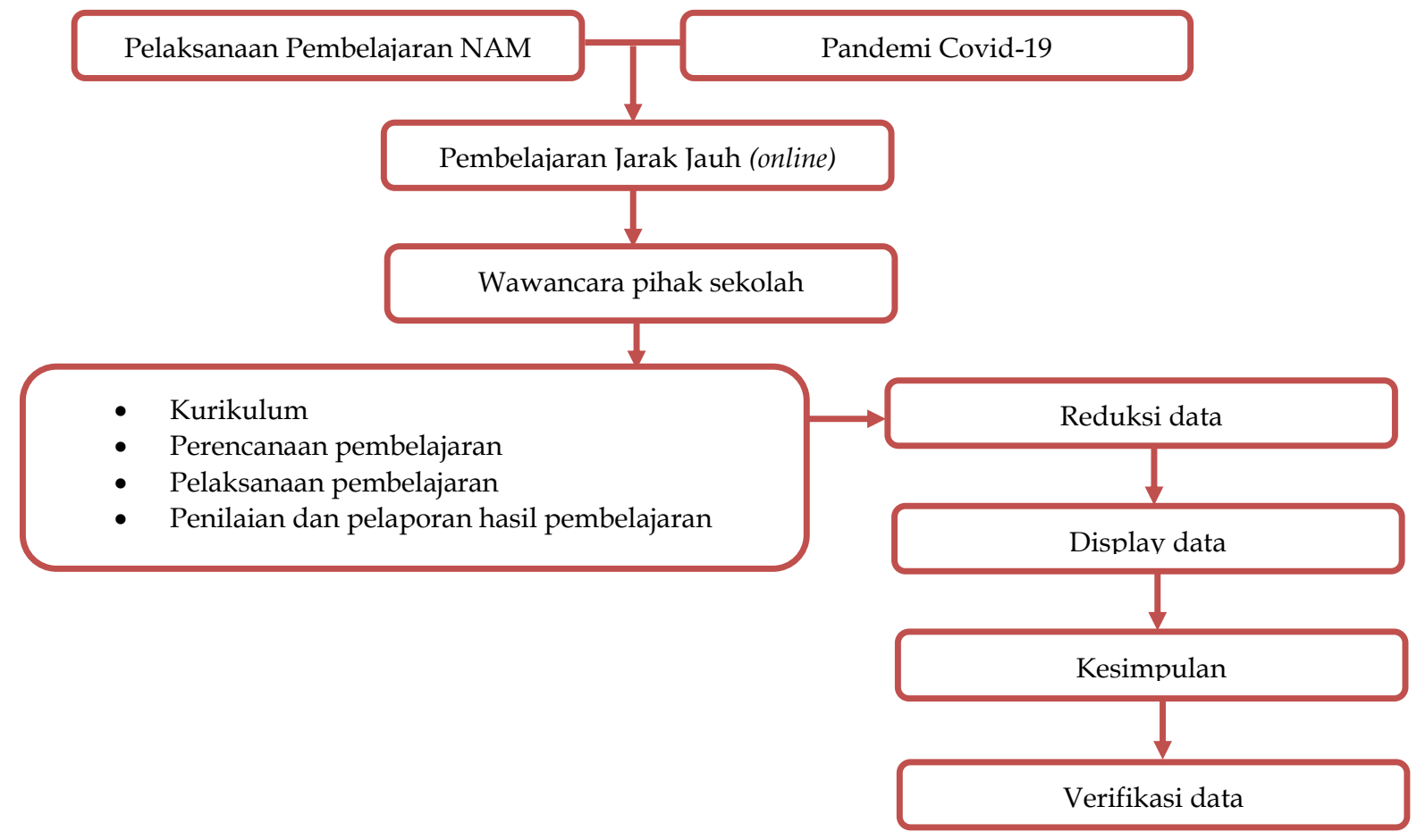

Gambar 1. Bagan Metode Penelitian 
Penelitian ini menggunakan wawancara mendalam untuk mengumpukan data dengan proses analisis melalui empat tahapan yaitu reduksi data, display data, kesimpulan, serta verifikasi data (Sugiyono, 2017). Penelitian ini dilakukan terhadap kepala sekolah, tim kurikulum, dan guru kelas TK A, TK B SAFA Islamic Preschool. Data wawancara diperoleh dengan wawancara mendalam dengan kepala sekolah, tim kurikulum, dan guru kelas dengan menanyakan pelaksanaan pembelajaran Nilai Agama dan Moral melalui pendekatan Montessori selama pandemi Covid-19 yang mencakup kurikulum, perencanaan pembelajaran, pelaksanaan pembelajaran, dan penilaian serta pelaporan hasil belajar anak kepada orang tua. Data yang tidak sesuai dengan fokus penelitian dihilangkan atau dibuang dan data yang sesuai dianalisis dan dijabarkan menggunakan pendekatan deskriptif. Penelitian dilakukan pada bulan Oktober 2020. Desain penelitian pada artikel ini dapat dilihat pada gambar 1.

\section{HASIL DAN PEMBAHASAN}

\section{Kurikulum di SAFA Islamic Preschool}

SAFA Islamic Preschool merupakan salah satu PAUD di Yogyakarta yang peduli terhadap pendidikan anak usia dini yang merupakan langkah awal penting dalam kehidupan seseorang. Hal ini dikarenakan pada usia dini, terjadi masa emas (golden age) di mana semua informasi yang didapatkan anak mampu diserap anak dengan cepat (Fauziddin, 2016a).

"SAFA adalah salah satu lembaga PAUD yang peduli betapa pentingnya pendidikan untuk anak usia dini diselenggarakan." "Di sekolah ini, kami meyakini bahwa semua anak merupakan pribadi yang unik, maka kami membantu anak untuk mengembangkan juga menggali potensi yang anak miliki." SAFA Islamic Preschool percaya bahwa setiap anak dilahirkan unik dan sebaik-baiknya seseorang adalah menjadi yang terbaik dari dirinya sendiri (be the best of themselves). SAFA Islamic Preschool membantu anak untuk mengembangkan seluruh potensi pribadinya. Hal ini sesuai dengan pendapat Srtyowati (2013) bahwa anak merupakan individu yang unik dan berharga.

SAFA Islamic Preschool menyampaikan kurikulum nasional dan sudah diperkaya dengan prinsip-prinsip montessori bernafaskan islam yang terkandung dalam setiap proses pembelajaran. SAFA Islamic Preschool mendasarkan pada pengenalan ajaran islam sejak dini. "Kurikulum yang kami gunakan di sekolah adalah kurikulum nasional 2013, kemudian kami juga mengadaptasi pendekatan montessori yang kami padukan dengan ajaran agama Islam." Sesuai dengan Permendikbud nomor 146 tahun 2013, kurikulum yang digunakan dalam lembaga PAUD adalah Kurikulum 2013 Pendidikan Anak Usia dini yang mengacu pada standar nasional PAUD (Kementerian Pendidikan dan Kebudayaan, 2013).

Berdasarkan hasil wawancara dengan sekolah, SAFA Islamic Preschool memperhatikan kebutuhan setiap anak berbeda-beda dalam belajar. "Di SAFA, program belajar kami rancang khusus untuk setiap anak dengan mengikuti gaya belajar anak, anak bebas menentukan akan bermain atau belajar apa. Tentunya lingkungan belajar yang kami sediakan juga mendukung setiap aktivitas anak. Sehingga harapan kami kedepannya anak dapat menjadi mandiri dan kreatif." Hal ini sejalan dengan Wulandari (2018) yang menekankan bahwa metode Montessori menekankan pembelajaran yang mengutamakan kebebasan, kebebasan atau freedom disini ialah kebebasan dalam memilih kegiatan dan kebebasan bermain agar anak tumbuh dan berkembang sesuai tempo dan kecepatan anak. Selain itu, anak akan lebih kreatif dan mandiri. Metode Montessori tidak mengharuskan anak pintar dalam kognitif saja, tetapi juga pintar dalam hal lain yang menyangkut keterampilan hidup. Pendapat lain menegaskan bahwa metode montessori merupakan metode mendidik anak sesuai dengan fitrahnya sebagai seorang anak. Metode ini memfokuskan pada kepentingan anak secara individu (child/student centered). Mereka akan melakukan aktivitas sehari-hari sesuai dengan pilihan dan keinginan mereka, sementara guru akan berperan sebagai fasilitator dalam semua kegiatan yang mereka lakukan. Selain itu, pembelajaran dengan metode montessori menekankan keterlibatan anak secara aktif, interaktif dan bervariasi yang melibatkan seluruh panca indera sehingga segala informasi yang disampaikan guru dapat diterima dengan maksimal (Nudin, 2017). 
Mengenai ajaran agama Islam yang diterapkan di SAFA Islamic Preschool merupakan ajaran agama dasar dan sederhana yang sering dilakukan anak dalam kehidupan sehari-hari. "SAFA mendasarkan pada pengenalan ajaran islam sejak dini. Pengenalan ini tidak hanya ditemukan dalam praktik ibadah ataupun sekadar hafal rukun islam dan rukun iman, akan tetapi juga dalam praktik sehari-hari, seperti senyum yang ramah, sikap yang santun, pembiasaan mengucap basmallah dan hamdallah setiap memulai dan selesai melakukan kegiatan, shalat dhuha, membaca iqro', cinta akan kebersihan, semangat dalam belajar serta bersyukur kepada Allah SWT atas segala karunia-Nya." Berdasarkan hasil wawancara dapat terlihat bahwa pihak sekolah setuju bahwa penanaman nilai agama dan moral harus ditanamkan sedini mungkin. Hal ini selaras dengan pendapat Ananda (2017) bahwa guru PAUD harus mendidik anak usia dini dengan berlandaskan nilai moral dan agama agar anak mempunyai kepribadian yang baik.

\section{Perencanaan Pembelajaran selama Pandemi Covid-19 oleh Tim Kurikulum}

Kurikulum di SAFA Islamic Preschool di susun oleh tim kurikulum, berdasarkan wawancara dengan tim kurikulum berikut adalah peranan tim kurikulum dalam pelaksanaan pembelajaran, yaitu merancang kurikulum pembelajaran seperti merancang program tahunan, program semester, program mingguan (RPPM), serta penilaian pembelajaran peserta didik. "Peran tim kurikulum sekolah pada intinya adalah merancang kurikulum yang akan digunakan sekolah selama satu tahun ajaran, di mana mencakup program tahunan, program semester, program mingguan, program harian, sampai ke penilaian."Peran tim kurikulum juga mengkoordinir rekan kerja satu kelas dalam pembagian tugas yang terkait dengan pembelajaran."Kami juga melakukan koordinir guru dalam satu kelas untuk pelaksanaan pembagian tugas saat pembelajaran." Selain itu peran tim kurikulum mengevaluasi pembelajaran yang telah berlangsung sebelumnya, apabila dirasa sudah tepat, maka tetap dilanjutkan namun, apabila dirasa masih ada yang kurang tepat seperti pemilihan tema/sub tema dan format kurikulum maka peran tim kurikulum memperbaiki dan mencari solusi agar menjadi lebih baik lagi. "Selanjutnya, kami juga melakukan evaluasi terhadap kurikulum yang sudah berlangsung, apakah sudah sesuai atau perlu perbaikan mengenai semua hal yang berkaitan dengan proses belajar mengajar." Hal ini sesuai dengan pendapat Sa'ud, dkk (2005) mengenai penyusunan kurikulum yang harus memperhatikan kebutuhan lembaga dan merumuskan susunan kurikulum mulai dari tujuan, isi, pelaksanaan, dan evaluasi.

Ada beberapa pertimbangan tim kurikulum dalam menyusun kurikulum selama pandemi, yaitu disesuaikan dengan keadaan sekolah dan orang tua mengingat pandemi ini tentu membuat kondisi sekolah dan orang tua berbeda dari sebelumnya. Pembuatan materi pembelajaran disesuaikan dengan sumber daya manusia di dalam sekolah, sumber dana yang masuk dan kondisi orang tua seperti ada orang tua yang sibuk bekerja. Sehingga kegiatan pembelajaran dibuat lebih sederhana dan jumlah kegiatan lebih sedikit dari biasanya. Karena apabila diberikan kegiatan yang kompleks, rumit dan banyak, ada orang tua yang kesulitan dalam mendampingi anak-anak belajar di rumah. "Dalam masa pandemi ini kami sedikit melakukan perubahan dalam penyusunan kurikulum, harus disesuaikan dengan guru di sekolah, sumber dana yang ada, juga banyak orang tua yang sibuk bekerja menjadi pertimbangan kami."

Berdasarkan hasil wawancara terdapat perbedaan penyusunan kurikulum sebelum dan selama pandemi, penyederhanaan pemilihan acuan kompetensi dasar yang tertuang dalam RPPM dan pemilihan kegiatan bermain yang disesuaikan dengan kondisi sekolah dan orang tua. "Biasanya anak-anak bemain 4-5 kegiatan dalam satu hari ketika di sekolah namun selama pandemi menjadi 10 kegiatan dalam satu minggu. Asumsinya sehari anak-anak belajar 2 kegiatan dalam sehari. Pembelajaran melalui media zoom dilaksakaan seminggu 1 kali dengan duraasi 60 menit." Pramana (2020) juga berpendapat bahwa pelaksanaan pembelajaran anak usia dini sudah semestinya harus disesuaikan dengan keadaan saat ini di mana dilaksanakan dengan pembelajaran jarak jauh atau online. Terasa banyak perbedaan dalam pelaksanaan pembelajaran jarak jauh, mulai dari penyesuaian kurikulum, materi pembelajaran, hingga evaluasi hasil belajar anak. 
Sebelum pandemi Covid-19 sekolah menggunakan program harian (RPPH) untuk pedoman pelaksanaan pembelajaran, akan tetapi saat pandemi Covid-19 berlangsung sekolah menggunakan program mingguan (RPPM). "Dikarenakan kondisi pandemi, kami menggunakan program mingguan sebagai pedoman pembelajaran, menurut kami akan lebih efektid dan efisien dibandingkan kami membuat program harian". Menurut Nugraha (2018), Rencana Pelaksanaan Pembelajaran Mingguan (RPPM) adalah rencana kegiatan pembelajaran yang disusun untuk pelaksanaan belajar mengajar selama satu minggu. Selain itu menurut Hasbi, dkk (2020), menyatakan bahwa Kegiatan belajar mengajar jarak jauh anak tertuang dalam program mingguan (RPPM) yang dirancang sederhana dengan mencakup enam kegiatan memuat enam aspek perkembangan, serta kegiatan belajar mengajar jarak jauh dilaksanakan satu hari satu kegiatan dengan orang tua sebagai pendamping.

\section{Perencanaan Pembelajaran selama Pandemi Covid-19 oleh Guru Kelas}

Berdasarkan hasil wawancara dengan guru kelas, terjadi perubahan proses belajar mengajar yang awalnya tatap muka secara langsung berganti menjadi pembelajaran jarak jauh dengan menggunakan teknologi informasi. "Terdapat perubahan cara belajar yang kami lakukan saat ini, pandemi mengharuskan kami belajar online melalui aplikasi zoom meeting atau whatsapp." Hal ini juga dikemukakan oleh Pramana (2020) bahwa lembaga Pendidikan Anak Usia Dini (PAUD) harus menyesuaikan diri dalam menghadapi perubahan tatanan dalam proses belajar mengajar. Yang sebelumnya antara guru dan murid bisa kontak langsung dan berinteraksi, sekarang harus melakukan proses belajar jarak jauh dengan menggunakan fasilitas teknologi informasi yang tersedia.

Peran guru kelas dalam perencanaan pembelajaran selama pandemi Covid-19 masih sama dengan sebelum adanya pandemi, hanya saja harus ada penyesuaian materi dan media pembelajaran yang dapat dijangkau dan dipergunakan dengan mudah oleh orang tua dan anak di rumah. Perencanaan pembelajaran dirasa sangat penting untuk menjadi pedoman dalam pelaksanaan proses belajar mengajar demi tercapaikan tujuan yang diinginkan (Apriyanti, 2017). "Untuk perencanaan pembelajaran masih sama saja dengan sebelum adanya pandemi, kami sebagai guru kelas hanya perlu menyesuaikan materi dan media pembelajaran, agar orang tua dan anak tidak mengalami kesulitan saat pelaksanaan pembelajaran jarak jauh."Kemudian, guru juga harus menyesuaikan durasi waktu, hal ini dikarenakan proses pembelajaran jarak jauh tidak dapat dilaksanakan dengan durasi yang lama seperti saat pembelajaran tatap muka. "Kami juga harus memangkas waktu pembelajaran, agar dirasa tidak terlalu lama sehingga materi harus padat dan jelas." Selain itu, pada awal minggu guru juga membuat media pembelajaran selama satu minggu untuk diserahkan pada orang tua sebagai bahan belajar jarak jauh selama di rumah. Media pembelajaran yang dibuat oleh guru harus terlihat menarik agar anak juga bersemangat dalam belajar. "Media pembelajaran selama satu minggu akan diberikan kepada orang tua, sehingga suatu waktu guru harus menyiapkan media pembelajaran yang akan digunakan dalam pembelajaran jarak jauh selama seminggu itu. Kemudian, media harus dibuat semenarik mungkin bagi anak biar anak semangat belajar." Hal ini sesuai dengan pendapat Nugraha, dkk (2018), bahwa bahan pembelajaran harus menarik untuk mendukung berlangsungnya proses belajar mengajar agar dapat memunculkan rasa ingin tahu anak, mendorong anak untuk berpikir kritis dan kreatif.

\section{Pelaksanaan Pembelajaran Nilai Agama dan Moral melalui Metode Montessori selama Pandemi Covid-19}

Salah satu aspek perkembangan anak yang perlu dicapai adalah nilai agama dan moral. Apabila aspek perkembangan agama dan moral tercapai dengan baik, maka akan memotivasi anak untuk terbiasa bersikap dan berperilaku sesuai dengan nilai-nilai yang ada dalam kehidupan bermasyarakat (Ananda, 2017). Kemudian, pencapaian perkembangan nilai agama dan moral juga dapat menciptakan karakter baik pada anak guna terciptanya generasi penerus bangsa yang berbudi luhur (Saregar et al., 2019). Selain itu, berbagai kecakapan hidup 
anak akan terpenuhi dengan aspek perkembangan agama dan moral (Zulkifli \& Febrialismanto, 2018).

Berdasarkan Permendikbud nomor 146 tahun 2014 dijelaskan mengenai muatan kurikulum program pengembangan nilai agama dan moral mencakup perwujudan suasana belajar untuk berkembangnya perilaku baik yang bersumber dari nilai agama dan moral serta bersumber dari kehidupan bermasyarakat dalam konteks bermain. Kemudian, terdapat empat kompetensi inti yang memuat kompetensi dasar. Kompetensi Inti Kurikulum 2013 Pendidikan Anak Usia Dini merupakan gambaran pencapaian Standar Tingkat Pencapaian Perkembangan Anak pada akhir layanan PAUD usia 6 (enam) tahun. Sedangkan kompetensi dasar merupakan tingkat kemampuan dalam konteks muatan pembelajaran, tema pembelajaran, dan pengalaman belajar yang mengacu pada Kompetensi Inti. Rumusan Kompetensi Dasar dikembangkan dengan memperhatikan karakteristik dan kemampuan awal anak serta tujuan setiap program pengembangan. Berikut adalah kompetensi dasar yang memuat aspek perkembangan nilai agama dan moral.

Tabel 1. Kompetensi Dasar Nilai Agama dan Moral

\begin{tabular}{cl}
\hline No & \multicolumn{1}{c}{ Kompetensi Dasar } \\
\hline 1 & 1.1. Mempercayai adanya Tuhan melalui ciptaan-Nya \\
2 & $\begin{array}{l}\text { 1.2. Menghargai diri sendiri, orang lain, dan lingkungan sekitar sebagai rasa syukur kepada } \\
\end{array}$ \\
& Tuhan \\
& 2.13.Memiliki perilaku yang mencerminkan sikap jujur \\
4 & 2.14.Memiliki perilaku yang mencerminkan sikap rendah hati dan santun kepada orang \\
& tua, pendidik, dan teman \\
5 & 3.1. Mengenal kegiatan beribadah sehari-hari \\
7 & 3.2. Mengenal perilaku baik sebagai cerminan akhlak mulia \\
8 & 4.1. Melakukan kegiatan beribadah seharihari dengan tuntunan orang dewasa \\
\hline
\end{tabular}

Pendekatan Metode Montessori merupakan pendekatan yang berpusat pada anak atau student center approach, di mana dalam pembelajaran, anak yang menjadi fokus utama pembelajaran, dan tugas utama guru hanya mengamati saat anak memilih dan mengerjakan Montessori Apparatus. Montessori Apparatus dibuat untuk anak agar memahami konsep dengan benda yang konkret. Pendekatan siswa atau student centered approach menjadi ciri khas utama dalam pembelajaran menggunakan metode Montessori (Wulandari et al., 2018). "Sekolah kami menggunakan pendekatan pembelajaran yang berpusat pada siswa, kami berharap minta dan bakat anak akan selalu berkembang sesuai tahapnya." Pendekatan metode Montessori mementingkan bakat dan minat pada anak, mengajarkan anak konsep, dan belajar sesuai tahapan usia, dalam metode ini juga anak diajarkan kasih sayang dan bekerja sama. Dalam student centered approach, anak lebih aktif didalam kelas sehingga anak lebih percaya diri, merasa dihargai, dan memiliki citra diri yang positif. Pendekatan metode ini sesuai dengan tahapan usia anak, berjenjang dan berlevel (Wulandari et al., 2018). Di SAFA Islamic Preschool, anak-anak belajar sesuai area dan tahapannya, area pertama adalah area kehidupan praktis (practical life), area kedua adalah area indera (sensorial), area yang ketiga yaitu area budaya (culture), area yang keempat adalah bahasa (languange), dan area yang terakhir adalah area matematika (math) Berikut adalah contoh kegiatan pembelajaran nilai agama dan moral dengan metode montessori berdasarkan wawancara dengan guru kelas.kegiatan pembelajaran nilai agama dan moral melalui metode Montessori dapat dilihat pada tabel 2.

Peran orang tua sangat diharapkan dalam proses belajar di rumah. Diharapkan orang tua bisa mendampingi ketika anak belajar atau turut belajar bersama anak. Bisa membimbing, mengarahkan bahkan harus bisa mendidik bagi anaknya menggantikan peran guru yang biasanya mengajar di sekolah. Orang tua bisa membuat laporan perkembangan belajar siswa ke guru pembimbingnya dan dikomunikasikan hal-hal yang menghambat dalam proses 
penbelajaran, agar dapat ditemukan solusi pemecahannya (Pramana, 2020). "Dalam pembelajaran jarak jauh, guru sangat mengandalkan orang tua agar dapat mendampingi anak. Guru juga mengandalkan orang tua dalam proses evaluasi hasil belajar anak." Selama pandemi Covid-19, anak belajar jarak jauh melalui aplikasi zoom meeting, google meet, dan whatsapp. Durasi pembelajaran adalah selama 60 menit. "Jika sebelum pandemi anak-anak belajar tatap muka di sekolah, anak-anak dapat berinteraksi secara langsung dengan teman dan guru, kegiatan pembelajaran dapat dilaksanakan 4-5 kegiatan bermain dalam 1 hari, guru lebih mudah dalam melakukan asesmen penilaian anak karena melakukan pengamatan secara langsung dan berinteraksi langsung setiap hari dengan anak. Namun, selama pandemi, anak-anak belajar sendiri di rumah masing-masing, kegiatan pembelajaran dilaksanakan 10 kegiatan dalam 1 minggu (2 kegiatan dalam satu hari) namun tetap menstimulasi 6 aspek perkembangan anak."

Tabel 2. Kegiatan Pembelajaran Nilai Agama dan Moral melalui Metode Montessori

\begin{tabular}{|c|c|c|c|}
\hline No & KD & $\begin{array}{c}\text { Kegiatan } \\
\text { Pembelajaran }\end{array}$ & Metode Montessori \\
\hline 1 & 1.1 & $\begin{array}{l}\text { Memberi } \\
\text { makan kucing }\end{array}$ & $\begin{array}{l}\text { Kucing merupakan salah satu hewan ciptaan Tuhan. Anak } \\
\text { dapat mempercayai adanya Tuhan dengan mengenal ciptaan- } \\
\text { Nya. Serta mengajarkan keterampilan hidup praktik langsung } \\
\text { memberi makan kucing. }\end{array}$ \\
\hline 2 & 1.2 & $\begin{array}{l}\text { Panen buah } \\
\text { mangga }\end{array}$ & $\begin{array}{l}\text { Anak diajarkan keterampilan hidup memetik sendiri buah } \\
\text { mangga. Dengan hal ini anak akan lebih menghargai buah } \\
\text { mangga yang dipetik dan bersyukur karena telah diberikan } \\
\text { nikmat makanan dari Tuhan melalui buah mangga. }\end{array}$ \\
\hline 3 & 2.13 & $\begin{array}{l}\text { Membereskan } \\
\text { mainan }\end{array}$ & $\begin{array}{l}\text { Anak akan dipantau oleh guru saat bermain, misalkan ada } \\
\text { anak yang belum mau membereskan mainan. Guru harus } \\
\text { dapat memberi pengertian kepada anak untuk berkata jujur } \\
\text { mengapa anak belum mau ikut membereskan mainan. Secara } \\
\text { tidak langsung saat membereskan mainan anak juga belajar } \\
\text { keterampilan hidup mengenai kerapian. }\end{array}$ \\
\hline 4 & 2.14 & Memberi salam & $\begin{array}{l}\text { Anak dibiasakan untuk memberi salam saat bertemu orang lain } \\
\text { agar dapat selalu diterapakan di kesehariannya. }\end{array}$ \\
\hline 5 & 3.1 & $\begin{array}{l}\text { Mencuci alat } \\
\text { ibadah }\end{array}$ & $\begin{array}{l}\text { Anak diajarkan keterampilan hidup dengan belajar mencuci } \\
\text { alat ibadah dan mengenal ibadah sholat. }\end{array}$ \\
\hline 6 & 3.2 & $\begin{array}{l}\text { Menyampaikan } \\
\text { kembali cerita } \\
\text { saling tolong } \\
\text { menolong }\end{array}$ & $\begin{array}{l}\text { Anak diperkenalkan dengan sikap tolong menolong dan } \\
\text { belajar keterampilan berbahasa. }\end{array}$ \\
\hline 7 & 4.1 & Wudhu & $\begin{array}{l}\text { Anak belajar praktik tata cara berwudhu, secara tidak langsung } \\
\text { anak juga belajar keterampilan hidup memakai dan melepas } \\
\text { alas kaki sendiri. }\end{array}$ \\
\hline 8 & 4.2 & $\begin{array}{l}\text { Mendengarkan } \\
\text { cerita orang } \\
\text { lain }\end{array}$ & $\begin{array}{l}\text { Dengan mendengarkan cerita orang lain, maka anak akan } \\
\text { belajar untuk tidak menyela perkataan orang lain. }\end{array}$ \\
\hline
\end{tabular}

\section{Penilaian dan Pelaporan Perkembangan Anak selama Pandemi Covid-19}

Berdasarkan Permendikbud nomor 146 tahun 2014 penilaian adalah proses pengumpulan dan pengolahan informasi untuk mengukur capaian kegiatan belajar anak. Penilaian hasil kegiatan belajar oleh pendidik dilakukan untuk memantau proses dan kemajuan belajar anak secara berkesinambungan. Berdasarkan penilaian tersebut, pendidik dan orang tua anak dapat memperoleh informasi tentang capaian perkembangan untuk menggambarkan sikap, pengetahuan, dan keterampilan yang dimiliki anak setelah melakukan kegiatan belajar. "Penilaian hasil belajar harus selalu kami lakukan setiap minggunya, hal ini merupakan cara untuk mengetahui hasil tumbuh kembang anak di masa pandemi seperti sekarang." Pernyataan lain datang dari Maryani (2020), yang menyatakan dengan adanya 
penilaian ini, maka guru dan orangtua dapat mengetahui perkembangan belajar anak, mengamati hal-hal apa saja yang anak tahu, apa saja yang anak bisa, dan apa saja yang menjadi kebiasaan anak. Berdasarkan hasil pengamatan tersebut guru dapat merancang program pembelajaran sesuai dengan minat, kekuatan, dan kebutuhan anak. Program pembelajaran yang direncanakan dan disusun sesuai dengan profil perkembangan anak akan menstimulasi potensi anak menjadi anak yang kompeten.

Kegiatan belajar di PAUD menggunakan penilaian otentik. Penilaian otentik adalah penilaian terhadap proses dan hasil belajar untuk mengukur tingkat pencapaian kompetensi anak, meliputi kompetensi sikap (spiritual dan sosial), pengetahuan, dan keterampilan berdasarkan fakta yang sesungguhnya (Nugraha, A.; Ritayani, U.; Siantiyani, Y.; Maryati, 2018). "Pada kegiatan pembelajaran jarak jauh, penilaian kami lakukan dengan menggunakan teknik observasi melalui foto ataupun video yang dikirimkan oleh orangtua dan melalui hasil karya yang dibuat oleh anak, tanya jawab dengan orang tua, dan pengamatan saat pembelajaran zoom berlangsung." Pelaporan hasil perkembangan anak kami sempat melakukan yang drive thru, jadi orang tua hanya berada di depan gerbang sekolah untuk mengambil laporan perkembangan si anak. Tapi setelah adanya beberapa pertimbangan, kami melakukan penyerahan laporan hasil perkembangan anak secara tatap muka dengan tetap menjalankan protokol kesehatan dan pembatasan durasi konsultasi."" Laporan perkembangan anak kami sampaikan pada anak per tiga bulan dan per enam bulan atau satu semester."

Pada masa pandemi Covid-19 dengan kegiatan belajar dilakukan di rumah secara daring, guru tetap wajib melakukan penilaian di setiap kegiatan yang anak lakukan di rumah (Hasbi, M.; Wahyuni, M.; Yuliantina, 2020). Guru harus meluangkan lebih banyak waktu untuk memantau kegiatan maupun hasil dari kegiatan siswa, mengingat pekerjaan orang tua siswa bermacam-macam dan mencari waktu senggang untuk mendampingi anak melakukan kegiatan belajar maupun mengirimkan atau melaporkan kegiatan belajar anak selama di rumah. Melalui video dan foto yang dikirimkan oleh orang tua maupun melalui video call langsung dengan anak, guru dapat melakukan penilaian pada anak (Maryani, 2020).

\section{SIMPULAN}

Terdapat perbedaan pelaksanaan pembelajaran aspek nilai agama dan moral melalui metode montessori sebelum dan selama pandemi, mulai dari cara pelaksanaan, durasi pembelajaran, media pelaksanaan pembelajaran, hingga penilaian juga penyampaian hasil perkembangan anak yang dilakukan secara online. Pelaksanaan pembelajaran mulai dari perencanaan sampai pelaporan hasil perkembangan anak membutuhkan penyesuaian dengan kondisi anak dan orang tua yang akan menjalankan pembelajaran di rumah.

\section{UCAPAN TERIMA KASIH}

Peneliti mengucapkan terima kasih sedalam-dalamnya kepada Allah SWT atas limpahan dan karunianya sehingga peneliti dapat melaksanakan penelitian dan menyelesaikan artikel ilmiah ini. Dosen pembimbing yang telah memberikan arahan serta masukan selama menyusun karya ilmiah ini, orangtua yang telah memberikan doa dan dukungan kepada saya, SAFA Islamic Preschool selaku subjek penelitian atas kerjasamanya serta informasi yang diberikan sehingga penulis dapat menyelesaikan karya ilmiah ini serta semua pihak yang telah membantu penulis.

\section{DAFTAR PUSTAKA}

Aji, R. H. S. (2020). Dampak COVID-19 pada pendidikan di indonesia: Sekolah, keterampilan, dan proses pembelajaran. Salam: Jurnal Sosial Dan Budaya Syar-i.(7), 5, 395-402. https://doi.org/10.15408/sjsbs.v7i5.15314 
Ananda, R. (2017). Implementasi nilai-nilai moral dan agama pada anak usia dini. Jurnal Obsesi: Jurnal Pendidikan Anak Usia Dini, 1(1), 19-31. https://doi.org/10.31004/obsesi.v1i1.22

Apriyanti, H. (2017). Pemahaman Guru Pendidikan Anak Usia Dini Terhadap Perencanaan Pembelajaran Tematik. Jurnal Obsesi: Jurnal Pendidikan Anak Usia Dini, 1(2), 111-117. https://doi.org/10.31004/obsesi.v1i2.22

Azanella, L. A. (2020). Apa Itu PSBB hingga Jadi Upaya Pencegahan Covid-19. Editor: Inggried Dwi Wedhaswary. Kompas. Com.

Chan, J. F.-W., Yuan, S., Kok, K.-H., To, K. K.-W., Chu, H., Yang, J., Xing, F., Liu, J., Yip, C. C.Y., \& Poon, R. W.-S. (2020). A familial cluster of pneumonia associated with the 2019 novel coronavirus indicating person-to-person transmission: a study of a family cluster. The Lancet, 395(10223), 514-523. https:// doi.org/10.1016/S0140-6736(20)30154-9

Damayanti, E. (2020). Improving children independence through Montessori teaching method. Jurnal Obsesi: Jurnal Pendidikan Anak Usia Dini, 4(1), 475-482. https://doi.org/10.31004/obsesi.v4i1.333

Fauziddin, M. (2016a). Pembelajaran Agama Islam Melalui Bermain Pada Anak Usia Dini. Jurnal Obsesi: Jurnal Pendidikan Anak Usia Dini, 2(2), 107-116.

Fauziddin, M. (2016b). Peningkatan Kemampuan Kerja Sama melalui Kegiatan Kerja Kelompok Pada Anak Kelompok A TK Kartika Salo Kabupaten Kampar. Jurnal Obsesi: $\begin{array}{llll}\text { Jurnal Pendidikan Anak Usia 29-45. } & \end{array}$ https:// doi.org/10.31004/obsesi.v2i1.47

Hainstock. (2008). Kenapa Montessori? Mitra Media.

Hapsari, I. I. (2016). Psikologi Perkembangan Anak. Indeks.

Hasbi, M.; Wahyuni, M.; Yuliantina, I. (2020). Rencana Pelaksanaan Pembelajaran. Kementerian Pendidikan dan Kebudayaan.

Kementerian Pendidikan dan Kebudayaan, Pub. L. No. 20 (2003).

Kementerian Pendidikan dan Kebudayaan, Pub. L. No. 37 (2014).

Pedoman Pembatasan Sosial Berskala Besar dalam Rangka Percepatan Penanganan Corona Virus Disease, Pub. L. No. 9 (2020).

Kurikulum Pendidikan Anak Usia Dini, Pub. L. No. 146 (2013).

Lestariningrum, A. (2014). Pengaruh penggunaan media VCD terhadap nilai-nilai agama dan moral anak. Jurnal Pendidikan Usia Dini, 8(2), 195-206.

Mamun, M. A., Chandrima, R. M., \& Griffiths, M. D. (2020). Mother and son suicide pact due to COVID-19-related online learning issues in Bangladesh: An unusual case report. International Journal of Mental Health and Addiction, 1-4. https:// doi.org/10.1007/s11469-020-00362-5

Maryani, K. (2020). Penilaian dan Pelaporan Perkembangan Anak Saat Pembelajaran di Rumah di Masa Pendemi Covid-19. Murhum: Jurnal Pendidikan Anak Usia Dini, 4152. https://doi.org/10.37985/murhum.v1i1.4

Muthmainah, F. (2017). Penerapan Nilai-nilai Pendidikan Islam dalam Metode Maria Montessori di Brainy Bunch International Islamic Montessori School.

Nudin, B. (2017). Penanaman Nilai-Nilai Pendidikan Agama Islam pada Pendidikan Anak Usia Dini melalui Metode Montessori di Safa Islamic Preschool. Millah: Jurnal Studi Agama, 1, 41-62. https:// doi.org/10.20885/millah.vol16.iss1.art3

Nugraha, A.; Ritayani, U.; Siantiyani, Y.; Maryati, S. (2018). Pedoman Pengelolaan Pembelajaran Pendidikan Anak Usia Dini. Direktorat Pembinaan Pendidikan Anak Usia Dini, 2(50). https://doi.org/10.30651/didaktis.v18i3.1849

Organization, W. H. (2020). Coronavirus disease 2019 (COVID-19): situation report, 82.

Pramana, C. (2020). Pembelajaran Pendidikan Anak Usia Dini (PAUD) Dimasa Pandemi Covid-19. Indonesian Journal of Early Childhood: Jurnal Dunia Anak Usia Dini, 2(2), 115-123. https://doi.org/10.31004/obsesi.v5i1.592 
Sa'ud, Udin Syaefudin; Makmun; Abin, S. (2005). Perencanaan Pendidikan: Suatu Pendekatan Komphrehensif. Remaja Rosdakarya.

Saregar, A., Jamaludin, W., \& Septiani, R. (2019). Feasibility test of mobile learning with schoology: Efforts to foster the students' learning interest on magnetism. Journal of $\begin{array}{llll}\text { Physics: } & \text { Conference } & \text { Series, }\end{array}$ https://doi.org/10.1088/1742-6596/1155/1/012060

Setiawati, F. A. (2006). Pendidikan moral dan nilai-nilai agama pada anak usia dini: Bukan sekedar rutinitas. Paradigma, 1(02).

Setyowati, Y. (2013). Pola komunikasi keluarga dan perkembangan emosi anak (studi kasus penerapan pola komunikasi keluarga dan pengaruhnya terhadap perkembangan emosi anak pada keluarga Jawa). https://doi.org/10.24002/jik.v2i1.253

Sugiyono. (2017). Metode Penelitian Kuantitatif, Kualitatif, dan R\&D. Alfabeta.

Tim Kerja Kementerian Dalam Negeri. (2020). Pedoman Umum Menghadapi Pandemi COVID-19 Bagi Pemerintah Daerah; Pencegahan; Pengendalian; Diagnosis dan Manajemen. Kementerian Dalam Negeri Republik Indonesia.

Wulandari, D. A., Saefuddin, S., \& Muzakki, J. A. (2018). Implementasi pendekatan metode montessori dalam membentuk karakter mandiri pada anak usia dini. AWLADY: Jurnal Pendidikan Anak, 4(2), 1-19. https://doi.org/10.24235/awlady.v4i2.3216

Zhou, L., Wu, S., Zhou, M., \& Li, F. (2020). 'School's Out, But Class' On', The Largest Online Education in the World Today: Taking China's Practical Exploration During The COVID-19 Epidemic Prevention and Control As an Example. But Class' On', The Largest Online Education in the World Today: Taking China's Practical Exploration During The COVID-19 Epidemic Prevention and Control As an Example (March 15, 2020). https:// doi.org/10.2139/ssrn.3555520

Zulkifli, N., \& Febrialismanto, F. (2018). The Mapping of Development Strategy of Religious and Moral Values for Early Childhood in PAUD Kuok District, Kampar Regency. Proceedings of the UR International Conference on Educational Sciences, 726-733. 